\title{
Salvadora persica protects mouse intestine from eimeriosis
}

\author{
Salvadora persica protege o intestino do rato da eimeriose \\ Saleh Al-Quraishy'; Felwa Abdullah Thagfan ${ }^{1,2}$; Esam Mohamed Al-Shaebii'; Mahmood Qasem"; \\ Rewaida Abdel-Gaber ${ }^{1,3}$; Mohamed Abdel Monam Dkhil ${ }^{1,4 *}$ (1) \\ ${ }^{1}$ Department of Zoology, College of Science, King Saud University, Riyadh, Saudi Arabia \\ ${ }^{2}$ Department of Biology, College of Science, Princess Nourah bint Abdulrahman University, Riyadh, Saudi Arabia \\ ${ }^{3}$ Zoology Department, Faculty of Science, Cairo University, Cairo, Egypt \\ ${ }^{4}$ Department of Zoology and Entomology, Faculty of Science, Helwan University, Cairo, Egypt
}

Received May 14, 2019

Accepted July 26, 2019

\begin{abstract}
Eimeriosis is a global poultry health problem. In the current study, we investigated the role of Salvadora persica leaf extracts (SE) against murine eimeriosis induced by Eimeria papillata. The infection induced an oocyst output of $6242 \pm 731$ oocysts/g feces. After treatment with $300 \mathrm{mgkg} \mathrm{SE}$, the oocysts expelled in feces decreased by approximately 3 -fold. In addition, the total number of $E$. papillata in the parasitic stage decreased in the jejunum of mice after treatment with SE. In addition, SE significantly reduced the number of apoptotic cells by approximately 2-fold in the infected jejunum. SE ameliorated the changes in glutathione, malondialdehyde, and catalase due to E. papillata infection. Finally, SE regulated the cytokine genes, interleukin (IL)- $1 \beta$, IL-6, interferon- $\gamma$, and tumor necrosis factor- $\alpha$, and the apoptotic genes, B-cell lymphoma-2, Bax, and Caspase-3. SE protects the jejunum from E. papillata induced injury and may have potential therapeutic value as a food additive during eimeriosis.
\end{abstract}

Keywords: Salvadora persica, jejunum, apoptosis, oxidative stress, Eimeriosis.

\section{Resumo}

A eimeriose é um problema global de saúde avícola. No presente estudo, investigou-se o papel dos extratos de folhas de Salvadora persica (SE) contra a eimeriose murina induzida por Eimeria papillata. A infecção induziu uma produção de oocistos de $6242 \pm 731$ oocistos/g de fezes. Após o tratamento com $300 \mathrm{mgkg}$ SE, os oocistos eliminados nas fezes diminuíram em aproximadamente 3 vezes. Além disso, o número total de E. papillata no estágio parasitário diminuiu nos jejunos de camundongos após o tratamento com $\mathrm{SE}$. Da mesma forma, o $\mathrm{SE}$ reduziu significativamente o número de células apoptóticas em aproximadamente 2 vezes no jejuno infectado. O estudo mostrou que o SE melhorou as alteraçôes na glutationa, malonaldeído e catalase devido à infecçáo por E. papillata. Finalmente, o $\mathrm{SE}$ regulou os genes das citocinas, interleucina (IL) - $1 \beta$, IL-6, interferon- $\gamma$ e fator de necrose tumoral $\alpha$, e os genes apoptóticos, linfoma-2, Bax e Caspase-3. Assim, o SE protegeu os jejunos das lesóes induzidas por E. papillata e pode ter potencial valor terapêutico como aditivo alimentar durante a eimeriose.

Palavras-chave: Salvadora persica, jejuno, apoptose, estresse oxidativo, Eimeriose.

\section{Introduction}

Eimeriosis is a dangerous parasitic disease caused by the infection of animals with a protozoan parasite belonging to genus Eimeria (MEHLHORN, 2014). It causes severe problems in poultry and livestock that can cause huge economic losses (LONG, 1990). Although the drugs used against eimerioses like toltrazuril, monensin and paronomycin are effective, they cause some side effects to the infected host and resistance to the drugs can develop (WUNDERLICH et al., 2014). Natural sources

${ }^{*}$ Corresponding author: Mohamed A. Dkhil. Zoology Department College of Science, King Saud University, P.O. Box 2455, Riyadh- 11451, Riyadh, Saudi Arabia. e-mail: mohameddkhil@yahoo.com such as pomegranate, neem, and garlic have been evaluated as an alternative control to eimeriosis (WUNDERLICH et al., 2014). These agents are more effective and less harmful because they cause negligible side effects, exhibit low mammalian toxicity, and can be handled easily (WUNDERLICH et al., 2014; DESHPANDE et al., 2011).

Salvadora persica is a traditional medicinal plant used in Islamic countries for oral hygiene. It belongs to the family Salvadoraceae and is commonly termed the Meswak tree. The evergreen desert shrub is found in different regions of the world including the Middle East and Africa. Its roots and twigs have been used for teeth 
cleaning since ancient times (ELVIN-LEWIS, 1980; EID et al., 1990; SHER et al., 2010).

The medicinal properties attributed to $S$. persica include anti-microbial, anti-plaque, analgesic, anti-inflammatory, diuretic, alexiteric, anti-pyretic, aphrodisiac, astringent, and bitter stomach therapeutic activities (GALLETTI et al., 1993; DARMANI et al., 2006). The antihelmintic activity of aqueous and alcoholic root extract of $S$. persica has been evaluated (ABDUL MAJEED, 2011), against Pheretima posthuma. Recently, Dkhil et al. (2019) studied the antihelmintic and anticoccidial activities of $S$. persica root extracts in mice and reported the excellent modulation of oxidative damage induced by E. papillata infection in mice jejunum.

Most of the previous studies focused only on the root extract. In this study, $S$. persica leaf extract (SE) was used as an anti-eimerial, antioxidant, and anti-apoptotic agent in male C57Bl/6 mice.

\section{Materials and Methods}

\section{Leaf extraction and gas chromatography-mass spectrometry analysis}

Fresh leaves of $S$. persica were collected from Jazan Region, Saudi Arabia. The leaves were authenticated at the herbarium of the Botany Department, King Saud University. A methanolic extract was prepared as described previously (AMER et al., 2015). Briefly, the leaves were dried, ground to a powder using an electronic blender, and extracted with $70 \%$ methanol. The extract obtained was dissolved in water as a preparation to inoculate mice. Trace GC Ultra and ISQ Single Quadruple mass spectrometry (Thermo Fisher Scientific, Waltham, MA, USA) were used to analyze SE as previously described (HUANG et al., 2012). The flow rate was $1.5 \mathrm{~mL} / \mathrm{min}$. Identification of mass spectra was conducted using the Wiley 9, replib, and National Institute Standard and Technology databases.

\section{Animals}

Adult male C57Bl/6 mice (9-12 weeks old) were obtained from the animal facility of King Faisal Specialist Hospital Research Center. Mice were fed a standard diet and water ad libitum. The experiments (project number 198) were approved by state authorities and Saudi Arabian rules for animal protection were observed.

\section{Infection of mice}

Unsporulated oocysts of E. papillata were collected from feces of mice after several passages. This strain was kindly provided by Prof. Heinz (Heinrich Heine University, Germany). Oocyst sporulation was carried out in potassium dichromate. The sporulated oocysts were washed with sterile saline (ABDEL MONEIM, 2013). Using an epigastric tube, mice were orally gavaged with 1000 sporulated oocysts (AMER et al., 2015). The mice were allocated to five groups ( $n=5$ per group). The first group was the non-infected control group. They received $100 \mu \mathrm{L}$ saline daily for 5 days. Mice in the remaining groups were infected with 1000 sporulated E. papillata oocysts. One hour later, group three, four, and five began daily treatment with 300, 600 and $900 \mathrm{mg} / \mathrm{kg}$ of SE for 5 days. On day 5 postinfection with E. papillata sporulated oocysts, feces were collected and the oocyst output was measured as previously described (SCHITO et al., 1996). The oocyst number was expressed per gram feces.

\section{Parasitic stages}

Tissue paraffin sections were prepared as previously described (DRURY \& WALLINGTON, 1980). To differentiate the different parasitic stages in the jejunum of mice, the sections were stained with hematoxylin and eosin then enumerated for meronts, gamonts, and developing oocysts in the infected and infected-treated groups. Values were expressed in $10 \mathrm{VCU}$.

\section{Apoptotic changes by the TUNEL assay}

The terminal deoxynucleotidyl transferase mediated deoxyuridine triphosphate "dUTP" nick end labeling assay (TUNEL) was performed in mice jejuna using the TUNEL Apoptosis Detection Kit (GenScript, Piscataway, NJ, USA) according to the manufacturer's protocol. The number of TUNEL positive cells was counted as previously described (DKHIL et al., 2013; DKHIL, 2013).

\section{Oxidative status in the jejunum}

The jejunum from all the groups of mice were weighed and then immediately homogenized in phosphate buffer then centrifuged at $1000 \times \mathrm{g}$ for $10 \mathrm{~min}$ at $4^{\circ} \mathrm{C}$. The supernatant was collected and $10 \%$ of the volume was used for the assays. GSH and MDA levels were determined in the jejunum according to Ellman (1959) and Satoh (1978), respectively. In addition, catalase activity was estimated in mice jejunum as previously described (AEBI, 1984).

\section{Gene expression}

RNA was isolated from frozen jejunum samples following the standard RNA extraction protocol with Trizol (Peqlab Biotechnology, Erlangen, Germany) (DELIC et al., 2010). Using the DNA-free TM Kit (Applied Biosystems, Darmstadt, Germany), all RNA samples were reverse transcribed into cDNA following the manufacturer's protocol using the QuantiTect ${ }^{\mathrm{TM}}$ Reverse Transcription Kit (Qiagen, Hilden, Germany). Amplifications were performed using QuantiTect $^{\mathrm{TM}}$ SYBR $^{\oplus}$ Green PCR kit (Qiagen) and gene-specific QuantiTect ${ }^{\mathrm{TM}}$ primers (Qiagen) according to the manufacturer's instructions. Relative quantitative evaluation of the amplification data was done using Taqman75000 system (Applied Biosystems) normalized to $18 \mathrm{~S}$ rRNA. The following primers were purchased from Qiagen: IL-1 $\beta$ (Mm_Il1b_2_SG, Cat. No. QT01048355), IL-6 (Mm_Il6_1_SG, Cat. No. QT00138663), INF- $\gamma$ (Mm_Ifng_1_SG, Cat. No. QT01038821), TNF- $\alpha$ (Mm_Tnf_1_SG, Cat. No. QT00104006), Bax (Mm_Bax_1_SG, Cat. No. QT00102536), Bcl2 (Mm_Bcl2_3_SG, Cat. No. QT00156282), and caspase-3 
(Mm_Casp3_1_SG, Cat. No. QT00260169). The ${ }^{2-\Delta \Delta}$ CT method was used to determine the fold-change in mRNA expression (LIVAK \& SCHMITTGEN, 2001).

\section{Statistical analyses}

Statistical comparison among the studied groups was carried out using one-way analysis of variance (ANOVA). Duncan's t-test and a statistical package program (SPSS version 17.0) were used. The statistical significance for all data was set at $\mathrm{p} \leq 0.05$. The checks were made via tests and / or graphs of the residuals for normality and heterogeneity.

\section{Results}

Figure 1 shows the mass spectrum of SE. The phytochemical components present included $11 \alpha$-hydroxy-17 $\alpha$-methyl testosterone, 2,5-cyclohexadiene-1,4-dione,2,6-bis(1,1-dimethylethyl)-, prednisolone acetate, and bis(2-ethylhexyl) phthalate (Table 1).
On day 5 post-inoculation (p.i.), the expelled oocysts from the E. papillata infected mice were greatest (6242 \pm 731 oocysts/g feces). Treatment of infected mice with different doses of SE produced a significant decline in the total number of expelled oocysts, especially after treatment with $300 \mathrm{mgkg}$ SE $(2070.2 \pm 540.7$ oocysts $/ g$ feces; Figure 2).

The total number of intracellular E. papillata stages (meronts, gamonts, and developing oocysts) in the jejunal villi of the hematoxylin and eosin stained sections (Figure 3) was significantly decreased in infected mice treated with different doses of SE, especially with $300 \mathrm{mg} / \mathrm{kg}$. persica leaf extract (Table 2).

The numbers of TUNEL positive cells (Figure 4) were significantly higher during infection (30 \pm 5 apoptotic cells / 10 villous crypt units, VCU) compared to the non-infected jejunum ( $3 \pm 0.3$ apoptotic cells/10 VCU). The group treated with $300 \mathrm{mg} / \mathrm{kg} \mathrm{SE} \mathrm{displayed} \mathrm{a}$ significant reduction in apoptotic cell number by approximately $10 \pm 2$ apoptotic cells / 10 VCU (Figure 5).

E. papillata infection of mice caused a significant decrease in the level of glutathione (GSH) and catalase (Figure 6). Treatment

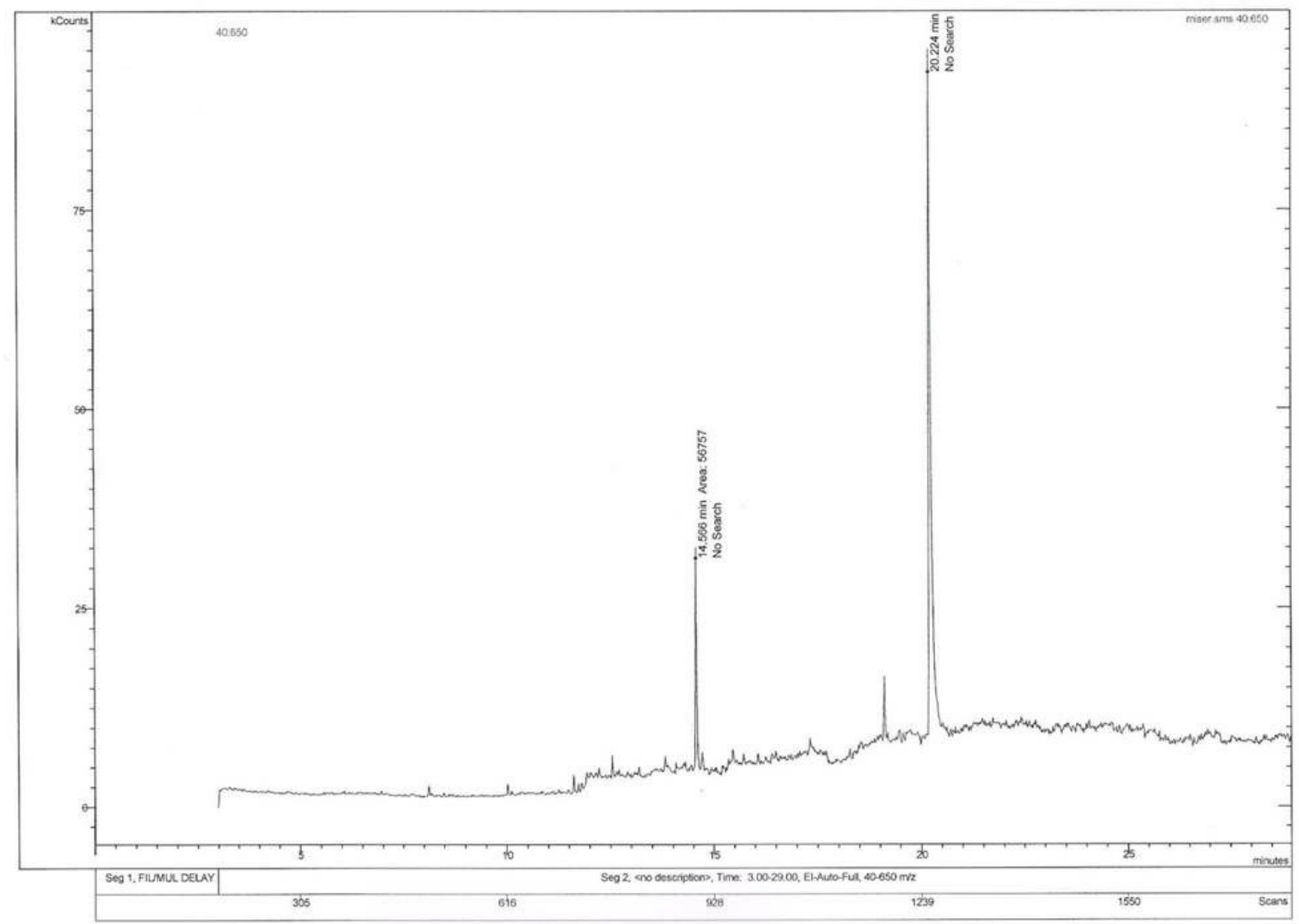

Figure 1. Gas chromatography-mass spectrometry chromatogram plot of aqueous leaf extract of $S$. persica.

Table 1. Identification of phytochemical compounds by GC-Mass in S. persica leaf extracts.

\begin{tabular}{clcccc}
\hline \multicolumn{1}{c}{ RT } & \multicolumn{1}{c}{ Assignment } & $\begin{array}{c}\text { Molecular } \\
\text { formula }\end{array}$ & {$[\mathbf{M}-\mathbf{H}]^{-}(\mathbf{m} / \mathbf{z})$} & MS (m/z) & Peak area (\%) \\
\hline 12.547 & 11 $\alpha$-Hydroxy-17 $\alpha$-methyl testosterone & $\mathrm{C}_{20} \mathrm{H}_{30} \mathrm{O}_{3}$ & 317 & $43-137$ & 22.6 \\
14.568 & 2,5-Cyclohexadiene-1,4-dione,2,6-bis(1,1-dimethylethyl)- & $\mathrm{C}_{14} \mathrm{H}_{20} \mathrm{O}_{2}$ & 219 & $41-205$ & 22.4 \\
19.111 & Prednisolone acetate & $\mathrm{C}_{23} \mathrm{H}_{30} \mathrm{O}_{6}$ & 401 & $15-404$ & 44.33 \\
20.221 & Bis(2-ethylhexyl) phthalate & $\mathrm{C}_{24} \mathrm{H}_{38} \mathrm{O}_{4}$ & 389 & $41-279$ & 7.18 \\
\hline
\end{tabular}




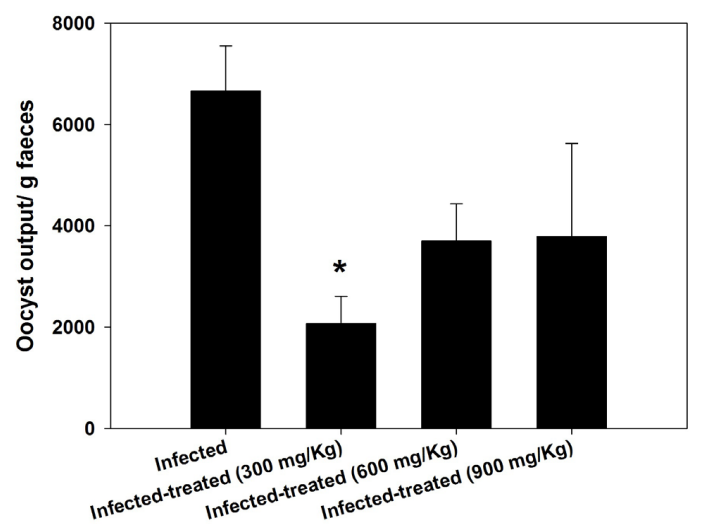

Figure 2. Changes in oocyst output after treatment of E. papillata infected mice with $S$. persica. $\left(^{*}\right)$ Significant change at $\mathrm{P} \leq 0.01$ with respect to the infected group. with $300 \mathrm{mg} / \mathrm{kg}$ SE produced a significant increase in the levels of GSH and catalase compared with both the non-infected and infected groups (Figure 6). Moreover, the infection induced a significant increase in the level of malondialdehyde (MDA) (Figure 6). Treatment with SE could improve this change in MDA (Figure 6).

Gene expression analysis of jejunum cytokines including interleukin (IL)-1 $\beta$, IL-6, tumor necrosis factor-alpha (TNF- $\alpha$ ), and interferon-gamma (IFN- $\gamma$ ) revealed upregulated expression of the genes in infected mice (Figure 7). Treatment of mice with SE induced the down-regulation of these genes (Figure 7). In addition, the apoptotic genes B-cell lymphoma 2 (Bcl2), BCL2-associated X (Bax), and caspase 3, which were upregulated in E. papillata infection, were significantly downregulated after treatment of mice with SE (Figure 8).
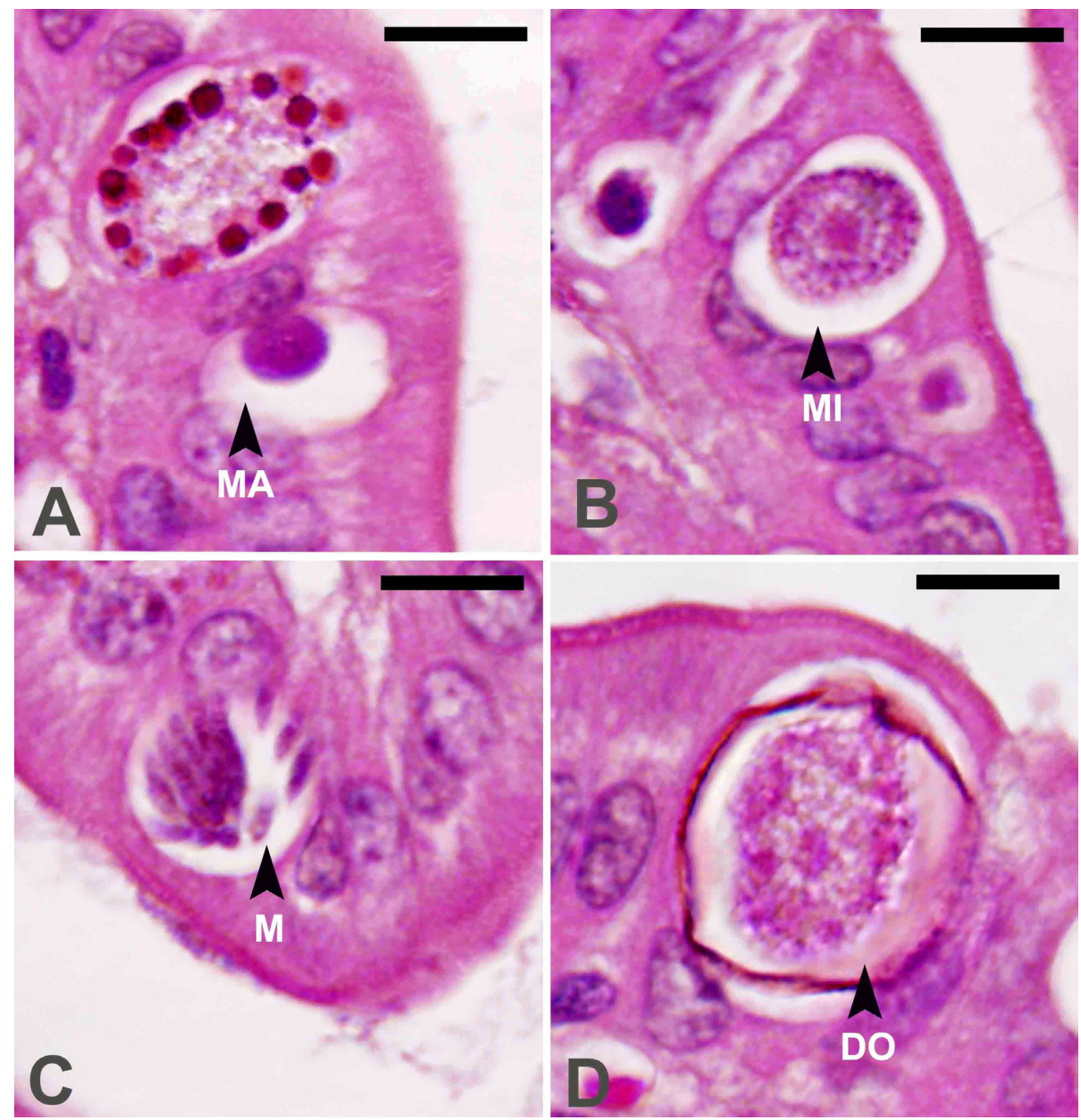

Figure 3. Parasitic stages of E. papillata in jejunum of mice. Meronts (M), microgamonts (MI), macrogamonts (MA), and developing oocysts (DO). Sections stained with eosin and hematoxylin. The bar $=10 \mu \mathrm{m}$.

Table 2. Parasitic stages in jejunum of E. papillata-infected and infected-treated mice with S. persica.

\begin{tabular}{lcccc}
\hline \multicolumn{1}{c}{ Group } & Meronts / 10 VCU & $\begin{array}{c}\text { Male and female } \\
\text { gamonts/ 10 VCU }\end{array}$ & $\begin{array}{c}\text { Developing } \\
\text { Oocysts / 10 VCU }\end{array}$ & $\begin{array}{c}\text { Total number of } \\
\text { parasitic stages }\end{array}$ \\
\hline Infected & $80.25 \pm 4$ & $25 \pm 3.5$ & $11.3 \pm 2.5$ & $116.5 \pm 10$ \\
Infected-treated $(300 \mathrm{mg} / \mathrm{Kg})$ & $35.7 \pm 4^{*}$ & $8.3 \pm 1.1^{*}$ & $6.75 \pm 2.5^{*}$ & $50.8 \pm 7.6^{*}$ \\
\hline
\end{tabular}

$\left(^{*}\right)$ Significance against infected group at $\mathrm{p}<0.01$. 

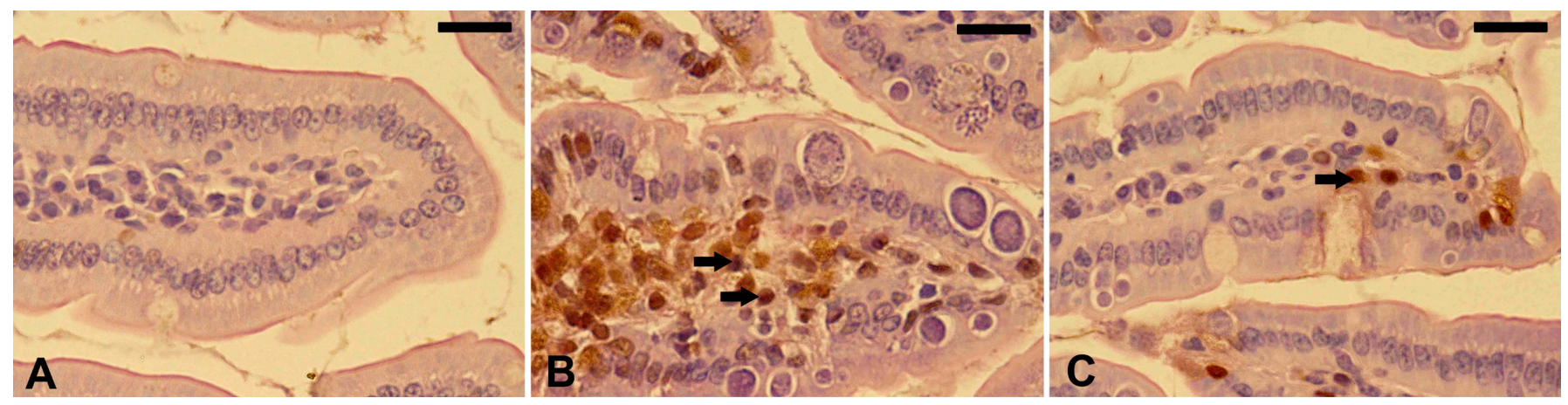

Figure 4. Changes in apoptotic cells in control (A), E. papillata infected (B), and infected-treated (C) mice jejunum. Brown cells represent a TUNEL positive cells. The bar $=50 \mu \mathrm{m}$.

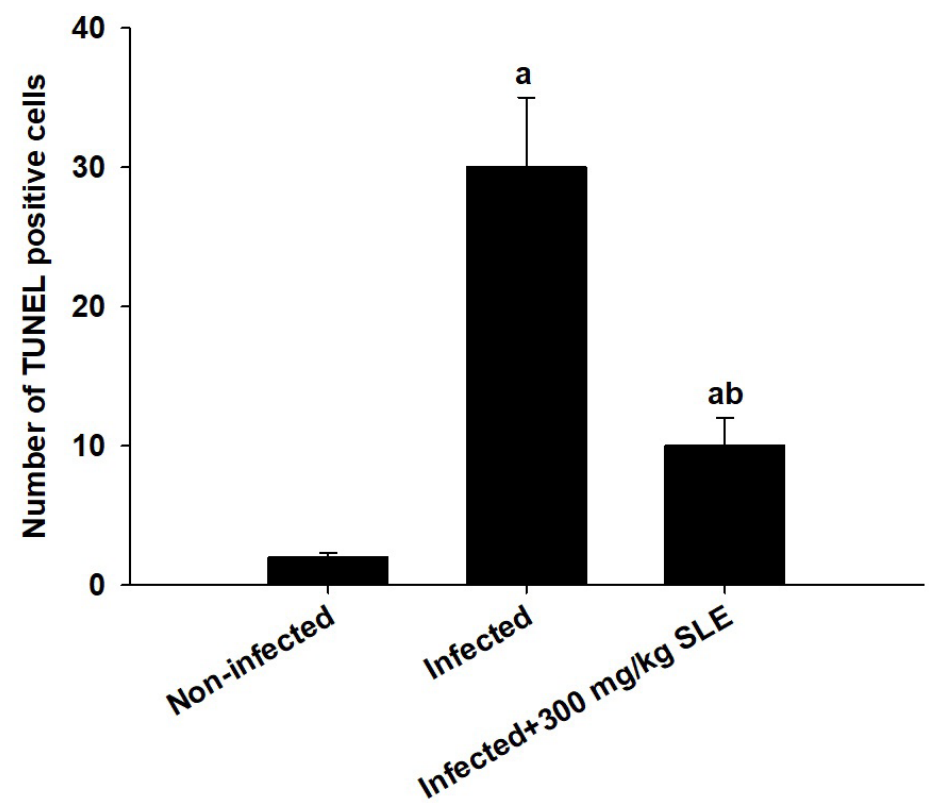

Figure 5. S. persica-induced changes in the apoptosis level in jejunum of mice. (a) Significant change at $\mathrm{P} \leq 0.05$ with respect to the non-infected group; (b) Significant change at $\mathrm{P} \leq 0.05$ with respect to the infected group.
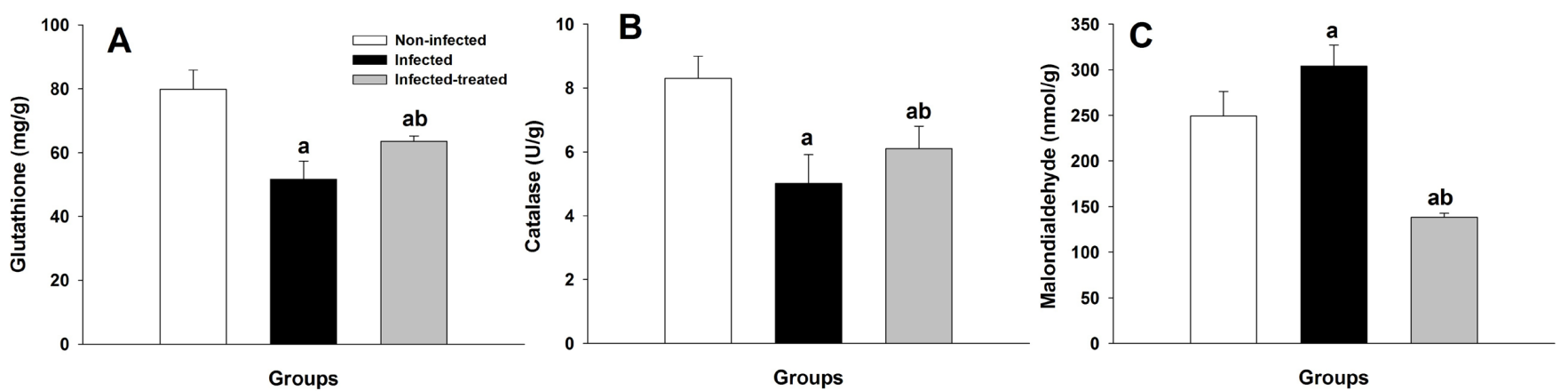

Figure 6. Effect of $S$. persica leaf extracts on glutathione (A) and malondialdehyde (B) levels, and catalase (C) activity in mouse jejunum infected with E. papillata. Data expressed as mean and standard deviation. (a) significant change against control animals; (b) significant change against infected animals. 

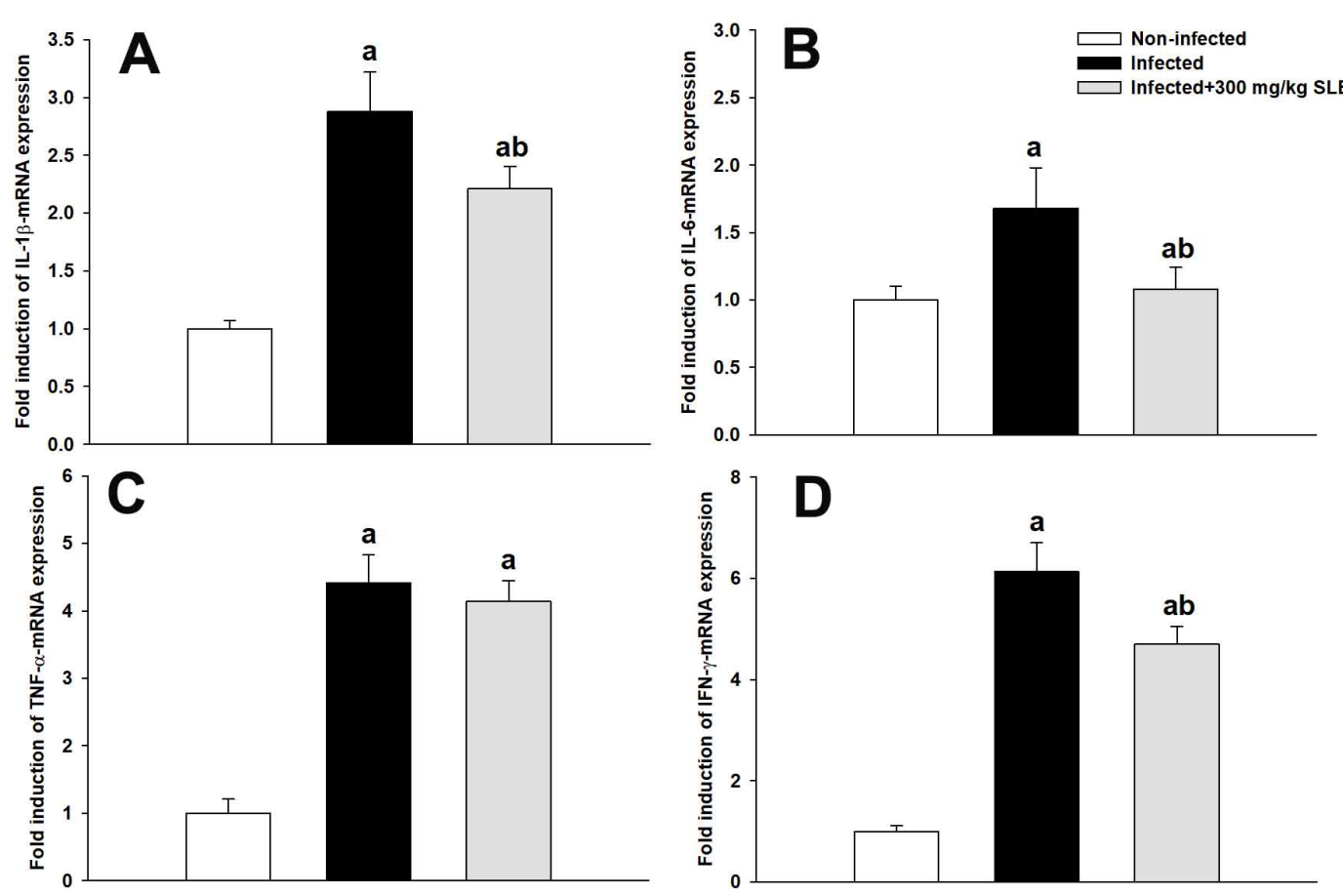

Figure 7. The level of jejunal IL-1 $\beta$ (A), IL-6 (B), IFN- $\gamma$ (C), and TNF- $\alpha$ (D) gene expression of control, E. papillata infected and infected-treated mice jejunum. (a) Significant change at $\mathrm{P} \leq 0.05$ with respect to the non-infected group; (b) Significant change at $\mathrm{P} \leq 0.05$ with respect to the infected group.

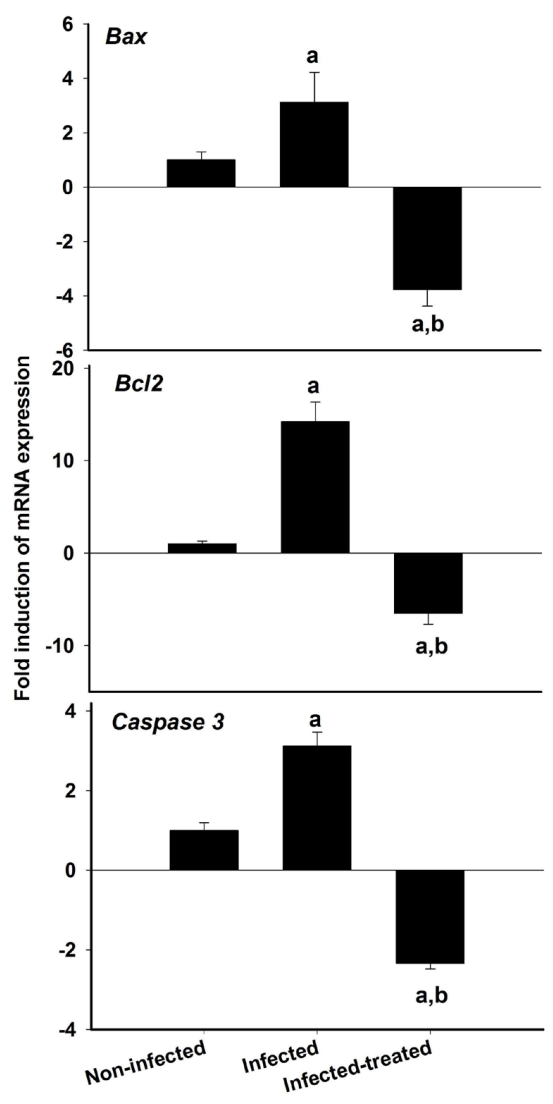

Figure 8. Apoptotic gene (Bcl2, Bax and Caspase 3) expression in control and E. papillata infected and infected-treated mice jejunum. (a) Significant change at $P \leq 0.05$ with respect to the non-infected group; (b) Significant change at $\mathrm{P} \leq 0.05$ with respect to the infected group.

\section{Discussion}

Several studies reported the anti-parasitic activities of several plant extracts (AMER et al., 2015; ALZAHRANI et al., 2016; DKHIL et al., 2019). The results of the present study demonstrate the potent anti-eimerial activity of SE against murine intestinal E. papillata infection. This effect may be due to the active ingredients present in the extract. Khan et al. (2010) found that SE contains flavonoids, glycosides, alkaloids, saponins, carbohydrates, tannins, and steroids. S. persica reportedly has beneficial therapeutic properties and the potency for use as an effective adaptogenic herbal therapy (AHMAD \& RAJAGOPAL, 2013).

Ahmad et al. (2011) reported significant anti-inflammatory activity of $S$. persica extract at a dose of $300 \mathrm{mg} / \mathrm{kg}$ in rats with induced paw edema. In our gas chromatography-mass spectrometry analysis, prednisolone acetate was identified as a component in SE. This compound is used as an anti-inflammatory agent (DANNI et al., 2019).

Presently, infection with E. papillata in mice caused intestinal tissue injury at the site of infection because of parasites at the developmental stages, especially merozoites, breaking out of the gut cells and invading other cells of the gut. The anti-eimerial activity of the extract resulted in a significant decrease in the number of the parasitic stages inside the jejunum. Palm pollen was reported to induce the same effect (METWALY et al., 2014). Moreover, selenium significantly reduced the number of meronts, gamonts, and developing oocysts of E. papillata (DKHIL et al., 2014).

Eimeria papillata infection is associated with oxidative damage in the jejunum of mice and severe local and systemic inflammatory responses (DKHIL et al., 2015). The authors further reported that 
this oxidative damage within the jejunum of infected mice was associated with a reduction in the activity of antioxidant enzymes, catalase, and glutathione peroxidase and depletion in the reduced GSH level. Intestinal infection with E. papillata in mice caused potential oxidative and cytotoxic damage within infected mucosal tissue as revealed by increased levels of nitric oxide and hydrogen peroxide, protein oxidation, and enhanced lipid peroxidation and depletion of the intracellular antioxidant defense system (DKHIL et al., 2015). Moreover, MDA, the most frequently used biomarker of oxidative stress, was significantly increased due to E. papillata infection. The SE was able to ameliorate the altered MDA level in mice jejunum.

Natural antioxidants obtained from $S$. persica have medicinal value in E. papillata infection. Some studies have suggested that two-thirds of the plant species on Earth have medicinal value, with several medicinal plants having significant antioxidant potential (KRISHNAIAH et al., 2011). The high therapeutic potential of S. persica reflects the anti-inflammatory (EZMIRLY et al., 1979) and antioxidant (MOHAMED \& KHAN, 2013) activities of the plant extract components. Ramadan and Alshamrani (RAMADAN \& ALSHAMRANI, 2015) described the potential anti-stress activity of $S$. persica aqueous extract. Salvadora persica inhibited stress-induced abnormalities in hematological parameters, glucose level, and lipid profile, indicating its protective effect against stress. The treatment of $E$. papillata infected mice with $S$. persica resulted in the pronounced modulation of oxidative damage and enhanced antioxidant capacity in the jejunum of mice.

The infection of mice with E. papillata caused jejunal inflammation as evidenced by the increased expression of mRNAs of the jejunal inflammatory cytokines, IL-1 $\beta$, IL- 6, TNF- $\alpha$, and INF- $\gamma$. Salvadora persica treatment regulated the induced changes in these cytokines, indicating the potential as a host defense against parasite-induced inflammation (SCHITO et al., 1998).

Apoptosis helps to eliminate cells infected by parasites (LÜDER et al., 2001; BALAMURUGAN et al., 2002). In addition, the upregulation of apoptotic genes within the jejunum of control non-infected mice is part of the normal function to maintain tissue homeostasis for the renewal of intestinal cells. E. papillata induced the regulation of $\mathrm{Bcl} 2$, Bax, and caspase- 3 . Bax activity stimulates the release of cytochrome $\mathrm{c}$, which in turn activates caspases to finally induce cell death (ROSSÉ et al., 1998). E. papillata invasion and replication might impose considerable stress on host cells (ALZAHRANI et al., 2016), which in turn triggers apoptosis (GREEN \& REED, 1998; GREEN, 2000). Other factors that stimulate apoptosis are the elevation of nitrogen intermediates, reactive oxygen species, and inflammatory cytokines within the intestinal epithelium (RAMACHANDRAN et al., 2000; MAJOR et al., 2011). Presently, SE administration significantly reduced the number of apoptotic cells in the jejunum of treated mice. Aqueous extracts of $S$. persica contain important molecules, such as benzyl isothiocyanate (ALALI \& AL-LAFI, 2003), which induce cell cycle arrest at the G2/M phase and apoptosis in human melanoma A375.S2 cells through reactive oxygen species and both mitochondria-dependent and multiple death receptor-mediated signaling pathways (HUANG et al., 2012). Salvadora persica possesses potent anticoccidial, antioxidant, anti-inflammatory, and antiapoptotic activities. Further studies are required to determine the mechanism of action of the extract on the parasite and the host.

\section{Acknowledgements}

The authors would like to thank the Deanship of Scientific Research and RSSU at King Saud University for their technical support. The work is supported by the Deanship of Scientific Research at King Saud University for funding this research group project No RG-198.

\section{References}

Abdel Moneim AE. The neuroprotective effects of purslane (Portulaca oleracea) on rotenone-induced biochemical changes and apoptosis in brain of rat. CNS Neurol Disord Drug Targets 2013; 12(6): 830-841. http://dx.doi.org/10.2174/18715273113129990081. PMid:23844694.

Abdul Majeed S. Anthelmintic activity of Salvadora persica root extract against Pheretima posthuma. Int J Pharm Sci Res 2011; 2(9): 2343-2346. http://dx.doi.org/10.13040/IJPSR.0975-8232.2(9).2343-46.

Aebi H. Catalase in vitro. Methods Enzymol 1984; 105: 121-126. http:// dx.doi.org/10.1016/S0076-6879(84)05016-3. PMid:6727660.

Ahmad H, Rajagopal K. Biological activities of Salvadora persica L. (Meswak). Med Aromat Plants 2013; 2(04): 129. http://dx.doi. org/10.4172/2167-0412.1000129.

Ahmad M, Imran H, Yaqeen Z, Rehman Z, Rahman A, Fatima N, et al. Pharmacological profile of Salvadora persica. PakJ Pharm Sci 2011; 24(3): 323-330. PMid:21715265.

Alali F, Al-Lafi T. GC-MS analysis and bioactivity testing of the volatile oil from the leaves of the toothbrush tree Salvadora persica L. Nat Prod Res 2003; 17(3): 189-194. http://dx.doi.org/10.1080/1057563021000 040790. PMid:12737403.

Alzahrani F, Al-Shaebi EM, Dkhil MA, Al-Quraishy S. In vivo anti-Eimeria and in vitro anthelmintic activity of Ziziphus spina-christi leaves extract. Pak J Zool 2016; 48(2): 409-413.

Amer OSO, Dkhil MA, Hikal WM, Al-Quraishy S. Antioxidant and anti-inflammatory activities of pomegranate (Punica granatum) on Eimeria papillata-induced infection in mice. BioMed Res Int 2015; 2015: 219670. http://dx.doi.org/10.1155/2015/219670. PMid:25654088.

Balamurugan K, Rajaram R, Ramasami T, Narayanan S. Chromium(III)induced apoptosis of lymphocytes: death decision by ROS and Src-family tyrosine kinases. Free Radic Biol Med 2002; 33(12): 1622-1640. http:// dx.doi.org/10.1016/S0891-5849(02)01115-2. PMid:12488131.

Danni R, Viljanen A, Aaronson A, Tuuminen R. Preoperative antiinflammatory treatment of diabetic patients does not improve recovery from cataract surgery when postoperatively treated with a combination of prednisolone acetate and nepafenac. Acta Ophthalmol 2019; 97(6): 589-595. http://dx.doi.org/10.1111/aos.14018. PMid:30620140.

Darmani H, Nusayr T, Al-Hiyasat AS. Effects of extracts of miswak and derum on proliferation of Balb/C 3T3 fibroblasts and viability of cariogenic bacteria. Int J Dent Hyg 2006; 4(2): 62-66. http://dx.doi. org/10.1111/j.1601-5037.2006.00149.x. PMid:16637906.

Delic M, Mattanovich D, Gasser B. Monitoring intracellular redox conditions in the endoplasmic reticulum of living yeasts. FEMS Microbiol Lett 2010; 306(1): 61-66. http://dx.doi.org/10.1111/j.1574-6968.2010.01935.x. PMid:20337710. 
Deshpande R, Kale A, Ruikar A, Panvalkar P, Kulkarni A, Deshpande $\mathrm{N}$, et al. Antimicrobial activity of different extracts of Juglans regia 1. against oral microflora. Int J Pharm Pharm Sci 2011; 3(2): 200-201.

Dkhil MA, Abdel-Baki AA, Wunderlich F, Sies H, Al-Quraishy S. Dietary selenium affects intestinal development of Eimeria papillata in mice. Parasitol Res 2014; 113(1): 267-274. http://dx.doi.org/10.1007/ s00436-013-3653-3. PMid:24221886.

Dkhil MA, Delic D, Al-Quraishy S. Goblet cells and mucin related gene expression in mice infected with Eimeria papillata. ScientificWorldJournal 2013; 2013: 439865. http://dx.doi.org/10.1155/2013/439865. PMid:24367242.

Dkhil MA, Hafiz TA, Thagfan FA, Al-Shaebi EM, Mubaraki MA, Khalil M, et al. Indigofera oblongifolia protects against trypanosomiasisinduced spleen injury. J Infect Public Health 2019. In press. http://dx.doi. org/10.1016/j.jiph.2019.03.005. PMid:30898472.

Dkhil MA, Metwaly MS, Al-Quraishy S, Sherif NE, Delic D, Al Omar SY, et al. Anti-Eimeria activity of berberine and identification of associated gene expression changes in the mouse jejunum infected with Eimeria papillata. Parasitol Res 2015; 114(4): 1581-1593. http://dx.doi. org/10.1007/s00436-015-4344-z. PMid:25663104.

Dkhil MA. Anti-coccidial, anthelmintic and antioxidant activities of pomegranate (Punica granatum) peel extract. Parasitol Res 2013; 112(7): 2639-2646. http://dx.doi.org/10.1007/s00436-013-3430-3. PMid:23609599.

Drury RAB, Wallington EA. Carleton's histological technique. 5th ed. Oxford: Oxford University Press; 1980. p. 188-291.

Eid MA, Selim HA, al-Shammery AR. Relationship between chewing sticks (Miswak) and periodontal health. Part 1. Review of the literature and profile of the subjects. Quintessence Int 1990; 21(11): 913-917. PMid:2084794.

Ellman GL. Tissue sulfhydryl groups. Arch Biochem Biophys 1959; 82(1): 70-77. http://dx.doi.org/10.1016/0003-9861(59)90090-6. PMid:13650640.

Elvin-Lewis M. Plants used for teeth cleaning throughout the world. $J$ Prev Dent 1980; 6: 61-70.

Ezmirly S, Cheng J, Wilson S. Saudi Arabian medicinal plants: salvadora persica. Planta Med 1979; 35(2): 191-192. http://dx.doi. org/10.1055/s-0028-1097205. PMid:419190.

Galletti GC, Chiavari G, Kahie YD. Pyrolysis/gas chromatography/ ion-trap mass spectrometry of the 'tooth brush' tree (Salvadora persica L.). Rapid Commun Mass Spectrom 1993; 7(7): 651-655. http://dx.doi. org/10.1002/rcm.1290070719.

Green DR, Reed JC. Mitochondria and apoptosis. Science 1998; 281(5381): 1309-1312. http://dx.doi.org/10.1126/science.281.5381.1309. PMid:9721092.

Green DR. Apoptotic pathways: paper wraps stone blunts scissors. Cell 2000; 102(1): 1-4. http://dx.doi.org/10.1016/S0092-8674(00)00003-9. PMid:10929706.

Huang SH, Wu LW, Huang AC, Yu CC, Lien JC, Huang YP, et al. Benzyl isothiocyanate (BITC) induces G2/M phase arrest and apoptosis in human melanoma A375.S2 cells through reactive oxygen species (ROS) and both mitochondria-dependent and death receptor-mediated multiple signaling pathways. J Agric Food Chem 2012; 60(2): 665-675. http://dx.doi.org/10.1021/jf204193v. PMid:22148415.

Khan W, Mujum A, Shaikh T, Katekar SM, Tambe R, Rub RA. Pharmacognostic and preliminary phytochemical investigation of Salvadora persica Linn (Salvadoraceae). Res J Pharmacog Phytochem 2010; 2(4): 319-323.
Krishnaiah D, Sarbatly R, Nithyanandam R. A review of the antioxidant potential of medicinal plant species. Food Bioprod Process 2011; 89(3): 217-233. http://dx.doi.org/10.1016/j.fbp.2010.04.008.

Livak K, Schmittgen TD. Analysis of relative gene expression data using real-time quantitative PCR and the $2^{-\Delta \Delta C T}$ Method. Methods 2001; 25(4): 402-408. http://dx.doi.org/10.1006/meth.2001.1262. PMid:11846609.

Long PL. Coccidiosis of man and domestic animals. Boca Raton: CRC Press; 1990.

Lüder CG, Gross U, Lopes MF. Intracellular protozoan parasites and apoptosis: diverse strategies to modulate parasite-host interactions. Trends Parasitol 2001; 17(10): 480-486. http://dx.doi.org/10.1016/S14714922(01)02016-5. PMid:11587962.

Major P, Revajová V, Levkut M, Ševčíková Z, Spišáková V, Faixová Z, et al. Intestinal mucin dynamic and leukocytic responses of chickens infected with Eimeria acervulina and fed oregano supplemented diet. Acta Vet Brno 2011; 80(2): 147-156. http://dx.doi.org/10.2754/avb201180020147.

Mehlhorn H. Encyclopedic reference of parasitology (4th ed.). Berlin: Springer; 2014.

Metwaly MS, Dkhil MA, Al-Quraishy S. Anti-coccidial and anti-apoptotic activities of palm pollen grains on Eimeria papillata-induced infection in mice. Biologia 2014; 69(2): 254-259. http://dx.doi.org/10.2478/ s11756-013-0297-9.

Mohamed SA, Khan JA. Antioxidant capacity of chewing stick miswak Salvadora persica. BMC Complement Altern Med 2013; 13(1): 40. http:// dx.doi.org/10.1186/1472-6882-13-40. PMid:23432926.

Ramachandran A, Madesh M, Balasubramanian KA. Apoptosis in the intestinal epithelium: its relevance in normal and pathophysiological conditions. J Gastroenterol Hepatol 2000; 15(2): 109-120. http://dx.doi. org/10.1046/j.1440-1746.2000.02059.x. PMid:10735533.

Ramadan KS, Alshamrani SA. Effects of Salvadora persica extract on the hematological and biochemical alterations against immobilizationinduced rats. Scientifica (Cairo) 2015; 2015: 253195. http://dx.doi. org/10.1155/2015/253195. PMid:26221565.

Rossé T, Olivier R, Monney L, Rager M, Conus S, Fellay I, et al. Borner C. Bcl-2 prolongs cell survival after Bax-induced release of cytochrome c. Nature 1998; 391(6666): 496-499. http://dx.doi.org/10.1038/35160. PMid:9461218.

Satoh K. Serum lipid peroxide in cerebrovascular disorders determined by a new colorimetric method. Clin Chim Acta 1978; 90(1): 37-43. http:// dx.doi.org/10.1016/0009-8981(78)90081-5. PMid:719890.

Schito ML, Barta JR, Chobotar B. Comparison of four murine Eimeria species in immunocompetent and immunodeficient mice. J Parasitol 1996; 82(2): 255-262. http://dx.doi.org/10.2307/3284157. PMid:8604093.

Schito ML, Chobotar B, Barta JR. Cellular dynamics and cytokine responses in BALB/c mice infected with Eimeria papillata during primary and secondary infections. J Parasitol 1998; 84(2): 328-337. http://dx.doi. org/10.2307/3284491. PMid:9576507.

Sher H, Al-Yemeni MN, Masrahi YS, Shah AH. Ethnomedicinal and ethnoecological evaluation of Salvadora persica L.: a threatened medicinal plant in Arabian Peninsula. J Med Plants Res 2010; 4(12): 1209-1215.

Wunderlich F, Al-Quraishy S, Steinbrenner H, Sies H, Dkhil MA. Towards identifying novel anti-Eimeria agents: trace elements, vitamins, and plantbased natural products. Parasitol Res 2014; 113(10): 3547-3556. http:// dx.doi.org/10.1007/s00436-014-4101-8. PMid:25185667. 